12. Dawn NEWS Internet Edition. Contaminated water blamed for gastro in Landhi. 2009 July 17 [cited 2010 Dec 20]. http://www.dawn. com/fixed/arch/arch_2009.html

13. Lawande RV, Ogunkanmi AE, Egler LJ. Prevalence of pathogenic free-living amebae in Zaire, Nigeria. Ann Trop Med Parasitol. 1979;73:51-6.

14. Cogo P E, Scaglia M, Gati S, Rosetti F, Alaggio R, Laverda AM, et al. Fatal Naegleria fowleri meningoencephalitis, Italy. Emerg Infect Dis. 2004;10:1835-7.
15. Sajjad SH, Hussain B, Khan MA, Raza A, Zaman B, Ahmed I. On rising temperature trends of Karachi in Pakistan. Clim Change. 2009;96:539-47. DOI: 10.1007/s10584-009-9598-y

Address for correspondence: Syed Faisal Mahmood, Department of Medicine, Aga Khan University Hospital, Karachi 75800, Pakistan; email: faisal.mahmood@aku.edu

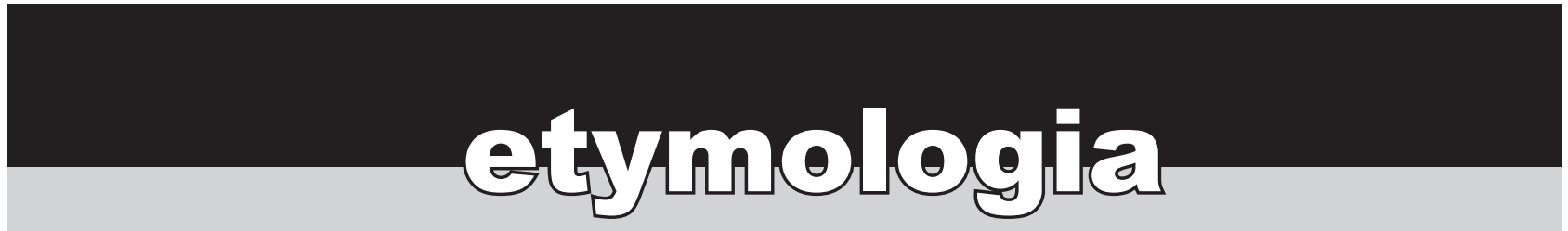

\title{
Naegleria fowleri
}

[nə'gliəriə fau(ə) $\left.1^{\prime} \cdot \partial r \cdot \overline{1}\right]$

From F.P.O. Nägler, an early 20th century bacteriologist, and Malcolm Fowler, an Australian physician. In 1912, A. Alexeieff proposed a new genus for questionable amoeboid forms, which he named Nägleria in honor of Nägler's work in identifying amoebae that pass through a biflagellate stage. Fifty-three years later, a report from Australia described human meningoencephalitis caused by an amebo-flagellate, later recognized as a member of Naegleria. In 1970, the pathogen was designated Naegleria fowleri after Fowler, who obtained one of the first isolates from human brain tissue.

Source: Alexeieff A. Sur less caractères cytologiques et la systématique des amibes du groupe limax (Naegleria nov gen et Hartmannia nov. gen) et des amibes parasites des vertebras (Proctamoeba nov. gen). Bull de la Soc Zool de France. 1912; 37:55; Calkins GN. Genera and species of ameba. In: Transactions of the Fifteenth International Congress on Hygiene and Demography, Vol. II, Washington, September 23-28, 1912. Washington: General Printing Office; 1913; Fowler M, Carter RF. Acute pyogenic meningitis probably due to Acanthamoeba sp.: a preliminary report. BMJ. 1965;2:740-2. DOI: 10.1136/ bmj.2.5464.734-a; Marciano-Cabral F. Biology of Naegleria spp. Microbiol Rev. 1998;52:114-33.

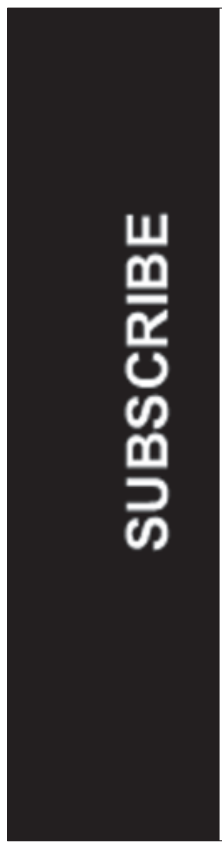

\section{EMERGING INFECTIOUS DISEASES}

$\square$ YES, I would like to receive Emerging Infectious Diseases. Please add me to your mailing list.

\section{Return:}

Email:

eideditor@cdc.gov

Fax: 404 639-1954

Mail to:

EID Editor

$\mathrm{CDC} / \mathrm{NCID} / \mathrm{MS}$ D61

1600 Clifton Rd, NE

Atlanta, GA 30333

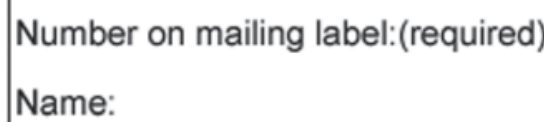

Full mailing address: (BLOCK LETTERS)

Full text free online at www.cdc.gov/eid 